\title{
PENGARUH MODAL SOSIAL DAN MANAJEMEN TERHADAP PENGEMBANGAN USAHA AGRIBISNIS DI SUBAK GEDE BUNGAN KAPAL KABUPATEN TABANAN
}

\author{
The Influence Of Social Capital And Management Towards Agri Culture Business \\ At Subak Gede Bungan Kapal Tabanan Regency
}

\author{
Ni Made Sukraeni Asih, Wayan Windia, Ni Wayan Sri Astiti
}

Program Studi Magister Agribisnis, Fakultas Pertanian, Universitas Udayana, Bali, Indonesia

Email: sukraeni_asih@yahoo.com

\begin{abstract}
Development in agriculture sector in Indonesia has some main agenda that is related with it's contribution toward poverty alleviation. On of the agenda is to develop economic activity in villages through agri culture economic development. In order to achieve it, there are several substances that supporting the substances. One of the substances are social capital and agriculture management. The aims of this research are $(i)$ to determine the influence of social capital towards the development of agriculture business at Subak Gede Bungan Kapal, (ii) to determine the influence of social capital towards management in agri culture in Subak Gede Bungan Kapal, and (iii) to determine the influence of agriculture management toward the development of agriculture business in Subak Gede Bungan Kapal. To know what is the influence that is formed in the research, Smart PLS and descriptive analysis is used in the data processing. Based on the Smart PLS analysis, some conclusion can be withdrawn for instance (i) social capital influence positively and very significant towards agriculture business development in Subak Gede Bungan Kapal Tabanan Regency, (ii) social capital influence positively and very significant towards agriculture management in Subak Gede Bungan Kapal, and (iii) management agriculture influence positively and very siginficant towards agriculture business development in Subak Gede Bungan Kapal. Based on the conclusion, suggestion that can be given is that the social capital in Subak Gede Bungan Kapal must be strengthen especially in changing the way the people think and widen the social network to advance the development of agriculture. The active role of every part in subak is really essential in developing agriculture activity. Hence, it is necessary to conduct an agri culture management training in terms of agriculture business activity in which it will help to develop the income of the Subak
\end{abstract}

Keywords: subak, social capital, management, agriculture development

\begin{abstract}
ABSTRAK
Pembangunan di sektor pertanian di Indonesia memiliki beberapa agenda utama yang terkait dengan kontribusinya terhadap pengentasan kemiskinan. Salah satu agendanya adalah mengembangkan kegiatan ekonomi di desa-desa melalui pengembangan ekonomi agribisnis. Untuk mencapainya, ada beberapa zat yang mendukung zat tersebut. Salah satunya adalah modal sosial dan manajemen pertanian. Tujuan dari penelitian ini adalah (i) untuk mengetahui pengaruh modal sosial terhadap pengembangan usaha pertanian di Subak Gede Bungan Kapal, (ii) untuk mengetahui pengaruh modal sosial terhadap manajemen dalam budaya pertanian di Subak Gede Bungan Kapal, dan (iii) untuk mengetahui pengaruh manajemen pertanian terhadap pengembangan bisnis pertanian di Subak Gede Bungan Kapal. Untuk mengetahui apa pengaruh yang terbentuk dalam penelitian, Smart PLS dan analisis deskriptif digunakan dalam pengolahan data. Berdasarkan analisis Smart PLS, beberapa kesimpulan dapat ditarik misalnya (i) pengaruh modal sosial positif dan sangat signifikan terhadap pengembangan usaha pertanian di Subak Gede Bungan Kapal Tabanan Kabupaten, (ii) pengaruh modal sosial positif dan sangat signifikan terhadap manajemen pertanian di Subak Gede Bungan Kapal, dan (iii) manajemen pertanian berpengaruh positif dan sangat signifikan terhadap pengembangan bisnis pertanian di Subak Gede Bungan Kapal. Berdasarkan kesimpulan, saran yang dapat diberikan adalah bahwa modal sosial di Subak Gede Bungan Kapal harus diperkuat terutama dalam mengubah cara berpikir masyarakat dan memperluas jaringan sosial untuk memajukan pembangunan pertanian.
\end{abstract}


Peran aktif setiap bagian dalam subak sangat penting dalam mengembangkan kegiatan pertanian. Oleh karena itu, perlu untuk mengadakan pelatihan manajemen agribisnis dalam hal kegiatan usaha pertanian di mana ia akan membantu untuk mengembangkan pendapatan Subak.

Kata kunci: subak, modal sosial, manajemen, pengembangan pertanian

\section{PENDAHULUAN}

\section{Latar Belakang}

Pembangunan sektor pertanian di Indonesia masih menjadi sektor terpenting dari keseluruhan pembangunan ekonomi mengingat Indonesia yang sebagian besar wilayahnya merupakan kawasan pertanian. Pertanian selain memproduksi bahan pangan kebutuhan masyarakat, juga bisa menghasilkan produk pertanian yang bisa di ekspor untuk dapat menambah pendapatan petani dan devisa negara. Pada dasarnya pembangunan sektor pertanian merupakan suatu upaya untuk meningkatkan pendapatan dan kualitas hidup petani. Oleh karena itu, harus dilaksanakan secara berkelanjutan melalui pengembangan kemampuan petani dalam mengelola usahataninya, agar selalu memiliki produktivitas yang tinggi, efisien, dan efektif serta memiliki daya saing yang dapat menjamin pendapatan dan kesejahteraan hidup keluarganya secara berkelanjutan

Di Provinsi Bali sektor pertanian adalah sektor utama yang sangat membantu . Pembangunan ekonomi. Ini dikarenakan pertanian merupakan bagian yang integral dari pembangunan ekonomi, pertanian merupakan satu-satunya sektor sebagai penghasil bahan makanan, baik bagi manusia maupun hewan ternak. Di Bali sektor pertanian berkaitan erat dengan sistem subak, karena subak mengelola sistem irigasi di sektor pertanian, subak juga mengatur pola dan jadwal tanam. sehingga sistem subak menjadi penunjang utama dari eksistensi sektor pertanian di Bali bahkan sistem subak dinilai memiliki peranan yang sangat nyata dalam proses pembangunan nasional melalui pengembangan kegiatan ekonomi subaknya. (Suyatna 1982).

Kegiatan pembangunan pertanian di Bali yang dilakukan melalui organisasi subak sudah dilakukan hampir ke seluruh kabupaten yang ada di Provinsi Bali salah satunya adalah Kabupaten Tabanan. Salah satu subak yang telah memulai aktifitas kegiatan agribisnisnya di Kabupaten Tabanan adalah Subak Gede Bungan Kapal. Subak ini berlokasi di Kecamatan Tabanan. Aktifitas agribisnisnya sudah dimulai sejak tahun 2005. Kegiatan agribisnis dimulai dengan adanya pemberian Bantuan Langsung Masyarakat (BLM) dalam kegiatan peningkatan produktifitas padi dan PTT oleh Dinas Pertanian Kabupaten Tabanan serta diinisiasi juga oleh Balai Pengkajian Teknologi Pertanian (BPTP) Provinsi Bali, dari bantuan tersebut sudah terbentuk KUAT sebagai lembaga pengerak ekonomi di Subak Gede Bungan Kapal. Keberhasilan suatu kegiatan pengembangan usaha agribisnis yang dijalankan dengan konsep usaha kecil pada sektor subak memerlukan adanya peran modal sosial dan manajemen di dalamnya agar semua kegiatanya dapat berjalan dengan baik. Dimana modal sosial dan manajemen merupakan ujung tombak dari suatu kegiatan agribisnis dalam suatu kelompok masyarakat seperti subak.

Modal sosial dalam kegiatan agribisnis berbeda dengan istilah populer lainnya yaitu modal manusia (human capital). Pada modal manusia segala sesuatunya lebih merujuk ke dimensi individu yaitu daya dan keahlian yang dimiliki oleh seorang individu. Pada modal sosial lebih menekankan pada potensi kelompok dan antar kelompok dengan ruang perhatian pada jaringan sosial, norma sosial dan kepercayaan antar sesama yang lahir dari anggota kelompok dan menjadi norma kelompok dalam mewujudkan kegiatan agribisnis. Modal Sosial sebagai sesuatu yang merujuk ke dimensi institusional, hubungan-hubungan yang tercipta, dan norma-norma yang membentuk kualitas dan kuantitas hubungan sosial dalam masyarakat. Disini modal sosial berperan dalam menjaga kepercayaan petani dalam kegiatan agribisnis serta menjaga kuantitas dan kualitas petani dalam menjalankan kegiatan agribisnisnya pada sektor subak. Modal sosial dan manajemen yang baik di dalam suatu pengembangan agribisnis subak dapat membantu tercapainya harmonisasi dan keberhasilan dari pengembangan usaha agribisnis.

\section{Rumusan Masalah}

Berdasarkan pada latar belakang di atas, secara umum dapat dirumuskan masalah dalam penelitian ini, di antaranya adalah sebagai berikut.

1. Bagaimana pengaruh modal sosial terhadap pengembangan usaha agribisnis di Subak Gede Bungan Kapal?

2. Bagaimana pengaruh modal sosial terhadap manajemen agribisnis di Subak Gede Bungan Kapal?

3. Bagaimana pengaruh manajemen agribisnis terhadap pengembangan usaha agribisnis di Subak Gede Bungan Kapal?

\section{Tujuan Penelitian}

Memperhatikan latar belakang dan rumusan masalah, maka tujuan penelitian ini sebagai berikut.

1. Mengetahui pengaruh modal sosial terhadap pengembangan usaha agribisnis di Subak Gede Bungan Kapal

2. Mengetahui pengaruh modal sosial terhadap manajemen agribisnis di Subak Gede Bungan Kapal 
3. Mengetahui pengaruh manajemen agribisnis terhadap pengembangan usaha agribisnis di Subak Gede Bungan Kapal

\section{TINJAUAN PUSTAKA}

\section{Modal Sosial}

Modal sosial (social capital) dapat didefinisikan sebagai kemampuan masyarakat untuk bekerja bersama, demi mencapai tujuan-tujuan bersama, di dalam berbagai kelompok dan organisasi (Coleman, 1999 dalam Sedana 2013). Secara lebih komperehensif (Burt 1992 dalam Sedana 2013) mendefinsikan, modal sosial adalah kemampuan masyarakat untuk melakukan asosiasi (berhubungan) satu sama lain dan selanjutnya menjadi kekuatan yang sangat penting bukan hanya bagi kehidupan ekonomi akan tetapi juga setiap aspek eksistensi sosial yang lain. (Putnam 1995 dalam Sudana 2013) mengartikan modal sosial sebagai features of social organization such as networks, norms, and social trust that facili-tate coordination and cooperation for mutual benefit. Modal sosial menjadi perekat bagi setiap individu, dalam bentuk norma, kepercayaan dan jaringan kerja, sehingga terjadi kerjasama yang saling menguntungkan, untuk mencapai tujuan bersama.

\section{Manajemen Agribisnis}

Manajemen Agribisnis adalah penerapan unsurunsur manajemen dalam organisasi agribisnis, sehingga aktivitas agribisnis dapat mencapai tujuan organisasi, misalnya efisiensi alokasi sumber daya, biaya minimal, keuntungan maks produksi, memenangkan persaingan, perluasan wilayah dalam satu sistem irigasi yang tergabung dalam satu wadah koordinasi dapat dihindari. pemasaran dan sebagainya. Manajemen agribisnis pada prinsipnya adalah penerapan manajemen dalam sistem agribisnis.(Antara 2005)

\section{Pengembangan Agribisnis}

Pengembangan Usaha Agribisnis Subak adalah kegitan pembangunan secara bertahap dan teratur yg menjurus ke sasaran yg dikehendaki pada sektor pertanian melalui kegitan agribisnis. Dimana sasaran yang ingin diukur diantaranya tingkat keuntungan, pembangunan, dan wujud dari pengembangan usaha. pengembangan kelembagaan dan SDM yaitu pengembangan organisasi dan terciptanya hubungan baik bagi sesama petani Subak maupun penyuluh.

\section{KERANGKA KONSEP DAN HIPOTESIS}

\section{Kerangka Konsep Penelitian}

Penelitian ini akan dilakukan untuk mengetahui pengaruh modal sosial dan manajemen agribisnis terhadap pengembangan usaha agribisnis di Subak Gede Bungan Kapal Kabupaten Tabanan. Berdasarkan studi teoritik dan empirik maka dapat disusun kerangka konseptual tentang variabelvariabel penelitian serta pengaruh maupun hubungan dari variabel tersebut. Modal soaial terdiri dari tiga indikator yaitu kepercayaan, norma sosial, dan jaringan sosial.

Manajemen agribisnis terdiri dari lima indikator yaitu perencanaan usaha agribisnis dalam Subak, pengorganisasian usaha agribisnis dalam Subak, pengkoorganisasian usaha agribisnis dalam Subak, pelaksanaan usaha agribisnis dalam Subak, pengawasan usaha agribisnis dalam Subak. Sedangkan variabel terikat pengembangan agribisnis terdiri dari lima indikator yaitu diantaranya berkembangnya kelembagaan dan sdm, berkembangnya usaha ekonomi subak, berkembangnya intensifikasi dan ekstensifikasi usaha tani, terciptanya lapangan kerja, dan meningkatnya pendapatan subak melaui peningkatan laba pada Koperasi subak

\section{Hipotesis Penelitian}

Berdasarkan rumusan masalah, kerangka berpikir dan kerangka konsep penelitian yang telah diuraikan sebelumnya, maka hipotesis dalam penelitian ini dapat dirumuskan sebagai berikut.

1. Terdapat pengaruh antara modal sosial terhadap pengembangan usaha agribisnis di Subak Gede Bungan Kapal Kabupaten Tabanan.

2. Terdapat pengaruh antara modal sosial terhadap manajemen agribisnis pada usaha agribisnis di Subak Gede Bungan Kapal Kabupaten Tabanan.

3. Terdapat pengaruh manajemen agribisnis terhadap Pengembangan usaha agribisnis di Subak Gede Bungan Kapal Kabupaten Tabanan.

\section{METODE PENELITIAN}

Penelitian ini dilakukan pada Subak Gede Bungan Kapal di Kabupaten Tabanan..Populasi dalam penelitian ini adalah pengurus dan anggota Subak, Subak Gede Bungan Kapal. Jumlah responden yang digunakan adalah 78 orang dari total keseluruhan anggota sebanyak 350 orang. Anggota terdiri atas seluruh anggota subak yang aktif. Variabel yang digunakan dalam penelitian terdiri atas variabel modal Sosial $\left(\mathrm{X}_{1}\right)$ yang terdiri dari kepercayaan $\left(\mathrm{X}_{1.1}\right)$, norma sosial $\left(\mathrm{X}_{1.2}\right)$, jaringan sosial $\left(\mathrm{X}_{1.3}\right)$, manajemen agribisnis $\left(\mathrm{X}_{2}\right)$ yang terdiri dari perencanaan usaha agribisnis dalam Subak $\left(X_{2.1}\right)$, pengorganisasian usaha agribisnis dalam subak $\left(\mathrm{X}_{2.2}\right)$, pengkoordinasian usaha agribisnis dalam Subak (X2.3), pelaksanaan usaha agribisnis dalam Subak (X2.4), pengawasan usaha agribisnis dalam Subak (X2.5), dan pengembangan usaha agribisnis subak (Y) yang terdiri dari 5 indikator yaitu pengembangan kelembagaan dan SDM (Y1), berkembangnya usaha, ekonomi subak (Y2), Meningkatnya insentif berusaha tani melalui 
peningkatan produksi dan efisiensi usaha tani (Y3), terciptanya lapangan kerja (Y4), dan meningkatnya pendapatan subak melaui pertambahan laba pada Koperasi subak. (Y5).

\section{Metode Analisis Data}

Analisis data dilakukan secara kuantitatif dan kualitatif. Analisis kuantitatif yang digunakan dalam penelitian ini adalah analisis SEM dengan PLS, sedangkan analisis kualitatifnya menggunakan analisis data deskriptif kualitatif.

\section{Analisis Deskriptif}

Metode deskriptif kualitatif merupakan metode penyajian, analisis, penafsiran data yang ada dengan tujuan mendeskripsikan suatu fenomena sosial yang disertai interpretasi terhadap faktor-faktor yang ada dilapangan. (Singarimbun dan Effendi, 1989 Data yang diperoleh kemudian didistribusikan dalam kategori berbeda-beda yaitu skor lima merupakan nilai skor tertinggi sedangankan satu merupakan nilai skor terendah Penentuan kategori dilakukan berdasarkan kelas-kelas interval tertentu dengan menggunakan rumus di bawah ini.

$$
\mathrm{i}=\text { jarak / jumlah kelas }
$$

\section{Metode analisis SEM dengan PLS}

Teknik analisis yang digunakan adalah model persamaan struktural (Structural Equation Modeling - SEM) berbasis variance atau Component based SEM, yang terkenal disebut Partial Least Square (PLS). PLS merupakan metode analisis yang powerfull, oleh karena tidak mengasumsikan data harus dengan pengukuran skala tertentu, jumlah sampel kecil, dan juga dapat digunakan untuk konfirmasi teori (Ghozali, 2008).

Menurut Ghozali (2011) tujuan PLS adalah membantu peneliti untuk tujuan prediksi. Model formalnya mendefinisikan variabel laten adalah linear agregat dari indikator-indikatornya. Weight estimate untuk menciptakan komponen skor variabel laten didapat berdasarkan bagaimana inner model (model struktural yang menghubungkan antar variabel laten) dan outer model (model pengukuran yaitu hubungan antara indikator dengan konstruknya) dispesifikasi. Hasilnya adalah residual variance dari variabel dependen.

\section{HASIL DAN PEMBAHASAN}

\section{Karakteristik Responden}

\section{Umur}

Tabel 1. Umur Responden

\begin{tabular}{cccc}
\hline No & $\begin{array}{c}\text { Umur } \\
\text { (Tahun) }\end{array}$ & Frekuensi & $\begin{array}{c}\text { Persentase } \\
(\boldsymbol{\%})\end{array}$ \\
\hline 1 & $25-36$ & 8 & 10.4 \\
2 & $37-48$ & 42 & $53 . .8$
\end{tabular}

\begin{tabular}{cccc}
3 & $49-60$ & 28 & 35.8 \\
\hline & Jumlah & $\mathbf{7 8}$ & $\mathbf{1 0 0}$ \\
\hline
\end{tabular}

Sebagian besar petani di Subak Gede Bungan Kapal berumur 37-48 tahun yaitu sebanyak 42 orang atau $53.8 \%$. Kondisi ini menunjukkan bahwa secara umum jika dilihat dari umur para responden, responden berada pada kelompok usia masih produktif, yaitu usia dimana kemampuannya dalam menumbuhkan dan menerapkan modal sosial dan manajemen dalam kegiatan agribisnis di ubak akan lebih berhasil lagi karena masih besar potensi tenaga kerja yang dimiliki dan produktivitas kerjanya dapat ditingkatkan lebih tinggi lagi dalam menjalankan kegiatan agribisnis dalam subak.

\section{Lama Pendidikan Formal}

Tabel 2. Lama pendidikan formal responden

\begin{tabular}{cccc}
\hline No & $\begin{array}{c}\text { Lama } \\
\text { Pendidikan } \\
\text { Formal } \\
\text { (Tahun) }\end{array}$ & $\begin{array}{c}\text { Frekuensi } \\
\text { (Orang) }\end{array}$ & $\begin{array}{c}\text { Persentase } \\
\mathbf{( \% )}\end{array}$ \\
\hline 1 & $<6$ & 0 & 0 \\
2 & $>6-9$ & 19 & 24.35 \\
3 & $>9-12$ & 48 & 61.53 \\
4 & $>12$ & 11 & 14.12 \\
\hline & Jumlah & $\mathbf{7 8}$ & $\mathbf{1 0 0}$ \\
\hline
\end{tabular}

Berdasarkan data diatas ditemukan bahwa rata-rata lama pendidikan formal petani sampel adalah 11.5 tahun, dengan kisaran antara dari 6 tahun sampai dengan 16 tahun. Ini berarti bahwa lama pendidikan formal petani sampel di Subak Gede Bungan kapal adalah setara dengan hampir tamat Sekolah Menengah Atas (SMA) dimana 61,53\% responden memiliki lama pendidikan formal $>9-12$. Keadaan yang demikian ini memberikan konsekuensi bahwa masyarakat anggota subak lebih mudah untuk diberikan wawasan mengenai pengembangan agribisnis.

\section{Luas Penguasaan Lahan}

Tabel 3. Luas Penggunaan Lahan Responden

\begin{tabular}{cccc}
\hline No & $\begin{array}{c}\text { Luas areal } \\
\text { sawah } \\
\text { (are) }\end{array}$ & $\begin{array}{c}\text { Frekuensi } \\
\text { (orang) }\end{array}$ & $\begin{array}{c}\text { Persentase } \\
(\%)\end{array}$ \\
\hline 1 & $20-27$ & 61 & 78.20 \\
2 & $28-35$ & 9 & 11.53 \\
3 & $36-42$ & 5 & 6.41 \\
4 & $43-50$ & 3 & 3.86 \\
\hline & Jumlah & $\mathbf{7 8}$ & $\mathbf{1 0 0}$ \\
\hline
\end{tabular}

Berdasarkan data yang disajikan pada Tabel 3 menunjukkan bahwa sebagian besar petani $(78,20$ $\%$ ) menguasai lahan sawah kisaran 20-27 are. Penguasaan lahan sawah di lokasi penelitian adalah relatif sempit sehingga menjadi skala yang kurang menguntungkan secara ekonomis untuk kegiatan pengembangan agribisnis utamanya pengembangan usahatani padi.

\section{Pekerjaan Utama}


Tabel 4. Pekerjaan Utama Responden

\begin{tabular}{cccc}
\hline No & Pekerjaan & $\begin{array}{c}\text { Frekuansi } \\
\text { (Orang) }\end{array}$ & $\begin{array}{c}\text { Persentase } \\
(\boldsymbol{\%})\end{array}$ \\
\hline 1 & Petani & 24 & 30.76 \\
2 & Buruh Tani & 23 & 29.48 \\
3 & Pegawai & 20 & 25.64 \\
& Swasta & & \\
4 & Pegawai & 11 & 14.1 \\
& Negeri Sipil & & \\
\hline & Jumlah & $\mathbf{7 8}$ & $\mathbf{1 0 0}$ \\
\hline
\end{tabular}

Berdasarkan pada Tabel 4 dapat dilihat bahwa sebagian besar pekerjaan pokok responden adalah sebagai petani yaitu $30.76 \%$, kondisi ini menunjukkan bahwa responden yang memiliki pekerjaan pokok sebagai petani akan lebih berpotensi mampu berperan aktif dalam kegiatan pengembangan usaha agribisnis karena intensitas bertani yang dilakukan lebih maksimal dibandingkan dengan yang pekerjaan pokoknya bukan sebagai petani

\section{Hasil Analisis Smart PLS}

Tabel 5. Koefisien Jalur Struktural Hubungan Antar Variabel

\begin{tabular}{lc}
\hline $\begin{array}{l}\text { Modal Sosial }\left(\mathrm{X}_{1}\right) \\
\text {->Pengembangan }\end{array}$ & 0.325 \\
Agribisnis $(\mathrm{Y})$ & \\
$\begin{array}{l}\text { Manajemen Agribisnis }\left(\mathrm{X}_{2}\right) \\
\text {->Pengembangan Agribisnis }\end{array}$ & 0.564 \\
$\begin{array}{l}\text { Modal Sosial }\left(\mathrm{X}_{1}\right) \\
\text {->Manajemen Agribisnis }\end{array}$ & 0.614 \\
\hline
\end{tabular}

Berdasarkan Tabel 5 di atas, dapat dibangun model persamaan hubungan regresi struktur yang terbentuk antara konstruk eksogen dengan konstruk endogen, sebagai berikut:

$$
\begin{aligned}
& \text { 1. } Y=0.325 X_{1}+0,564 X_{2} \\
& \text { 2. } X_{2}=0,614 X_{1}
\end{aligned}
$$

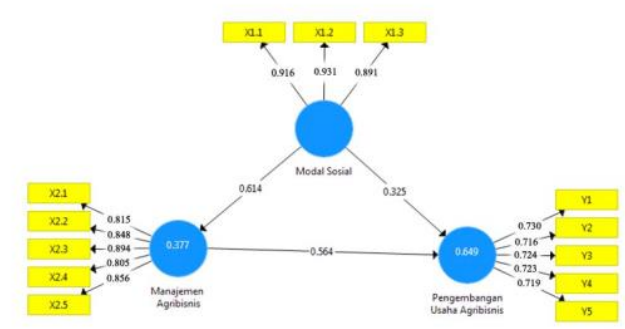

Gambar 1. Model Struktural

Berdasarkan hasil pada Gambar 5.1 diatas diketahui bahwa variabel modal sosial dan manajemen agribisnis terbukti berpengaruh positif dan signifikan terhadap pengembangan agribisnis dengan koefisien determinan (R2) sebesar 0.781. Hal ini menunjukkan bahwa variabel modal sosial dan manajemen agribisnis mampu menjelaskan variabel pengembngan agribisnis sebesar $78.1 \%$, sedangkan sisanya sebesar $21.9 \%$ dijelaskan oleh variabel lain diluar model.
Berdasarkan analisis Smart PLS maka didapatkan hasil sebagai berikut.

1. Pengaruh modal terhadap pengembangan agribisnis

Modal soaial (X1) terbukti berpengaruh positif dan sangat signifikan terhadap pengembangan agribisnis (Y). Hal ini dapat ditunjukkan oleh koefisien jalur yang bernilai positif sebesar 0.325 dengan t-statistik sebesar 3.948 (t-statistik > 2.64). sehingga hipotesis 1 (H1) : modal sosial berpengaruh positif terhadap pengembangan agribisnis dapat dibuktikan.

2. Pengaruh modal sosial terhadap penerapan manajemen agribisnis.

Modal soaial (X1) terbukti berpengaruh positif dan sangat signifikan terhadap manajemen agribisnis (X2). Hal ini dapat ditunjukkan oleh koefisien jalur yang bernilai positif sebesar 0.614 dengan t-statistik sebesar 7.590 (t-statistik > 2.64), sehingga hipotesis 2 (H2) : modal sosial berpengaruh positif terhadap manajemen agribisnis dapat dibuktika.

3. Pengaruh manajemen agribisnis terhadap $\mathrm{T}_{-}$pengembangan agribisnis Statistic $\overline{\text { Majemen Agribisnis (X2) terbukti berpengaruh }}$ 3.9480 sitif don sositif Sangat signifikan terhadap pengembangan agribisnis $(Y)$. ${ }^{\text {Hal }}$ ini dapat ditunjukkan oleh koefisien jalur yang bernilai positif 8.270) sebar 0.564 dengan th -statistik sebesar 8.270 (tstatistik > 2.64), sehitif. Dan Sangat hipotesis 3 (H3) : manajemen agribisnis Signipika

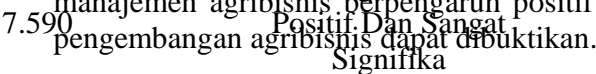

\section{Pengaruh modal sosial terhadap pengembangan agribisnis}

Berdasarkan hasil analisis Smart PLS yang dilakukan untuk mengetahui pengaruh antara modal sosial menunjukan bahwa adanya norma-norma atau aturan-aturan yang diterapkan pada subak dan koperasi menjadi salah satu landasan yang harus dipatuhi oleh petani sebagai anggota subak dalam beraktivitas termasuk pengembangan agribisnisnya.

Norma-norma ini mengikat seluruh anggota, pengurus subak dan koperasi di dalam kegiatan pengembangan agribisnis, yang selanjutnya mendorong petani untuk secara aktif berpartisipasi dalam beberapa aktivitas agribisnis seperti layanan penyediaan sarana produksi dan Alsintan, layanan kredit dan lain sebagainya. Penerapan norma sosial pada Subak Gede Bungan Kapal dalam menjalankan kegiatan pengembangan agribisnisnya yang paling menonjol yaitu setiap musim tanam jika ada anggota subak yang tidak membayar saprodi beserta alsintan yang sudah anggota beli pada koperasi subak pada musim tanam sebelumnya maka anggota subak tidak akan diijinkan untuk mengambil saprodi dan alsintan untuk kegiatan pertanianya untuk musim tanam selanjutnya sebelum pembayaran sisa hutang pada koperasi diselesaikan.. 
Aturan ini diterapkan oleh subak agar anggota subak disiplin dalam kegiatan agribisnis subak yang dijalankan karena jika anggota subak tidak dapat disipin maka pengembangan agribisnis yang telah berjalan dengan baik tidak dapat berlanjut lagi karena modal usaha yang terus berkurang akibat banyaknya piutang yang belum terselesaikan oleh anggota subak

\section{Pengaruh manajemen agribisnis terhadap pengembangan agribisnis}

Hasil analisis Smart PLS yang dilakukan menunjukan manajemen agribisnis berpengaruh positif dan sangat signifikan terhadap pengembangan usaha agribisnis di Subak Gede Bungan kapal. manajemen Agribisnis (X2) terbukti berpengaruh positif dan sangat signifikan terhadap pengembangan agribisnis (Y) hal ini menunjukkan bahwa subak pelaksana kegiatan agribisnis telah menerapkan unsur-unsur manajemen dari perencanaan, pengorganisasian, pengkoordinasian, pengembangan dan pengawasan kegiatan usahanya dengan baik sehingga mencapai keberhasilan dalam melaksanakan pengembangan usaha agribisnis. Berhasil tidaknya kegiatan agribisnnis pada dasarnya tergantung pada efektif tidaknya menerapkan unsur-unsur manajemen oleh subak pelaksana. Apabila penerapan manajemen agribisnis kurang dalam kegiatan pengembangan usaha agribisnis maka tingkat keberhasilan pun akan rendah.

Menurut Downey dan (Erickson 1992 dalam Dananjaya 2014), agar setiap aktivitas mencapai keberhasilan, maka memerlukan penerapan unsurunsur manajemen. Pada umumnya prinsip dan pengetahuan manajemen sama untuk semua bisnis, namun yang membedakannya terletak pada seni menggunakan prinsip dasar manajemen untuk menjalankan bisnis.

\section{Pengaruh modal sosial terhadap penerapan manajemen agribisnis.}

Dilihat dari hasil analisis Smart PLS dapat diketahui Modal soaial (X1) terbukti berpengaruh positif dan sangat signifikan terhadap manajemen agribisnis (X2) hasil analisis ini menunjukan bahwa modal sosilal sangat penting peranya dalam pelaksanaan manajemen agribisnis.. Modal sosial pada subak dapat membentuk SDM yang berkualitas sehingga dapat menerapkan manajemen agribisnis dalam kegiatan agribisnis. Modal sosial akan mempengaruhi perilaku seseorang agar dapat melakukan sesuatu atau memanajemen kegiatan secara maksimal sehingga subak menjadi lebih berhasil dalam menjalankan kegiatannya. Unsurunsur modal sosial sangat berkaitan terhadap kegiatan manajemen agribisnis penerapan unsur modal sosial yang baik di antara para petani dan pengurus subak dan koperasi telah memberikan kecendrungan yang positif bagi mereka untuk secara bersama-sama dalam memanjamen usaha agribisnisnya. Adanya tingkat penerapan modal sosial yang tinggi di antara para petani, pengurus subak dan koperasi mendorong tumbuhnya motifmotif atau dorongan untuk mendukung kegiatan agribisnis seperti penyediaan sarana produksi dan Alsintan, penyediaan kredit, pengolahan dan pemasaran.

\section{SIMPULAN DAN SARAN}

\section{Simpulan}

Berdasarkan hasil analisis dan pembahasan yang telah dilakukan dalam penelitian ini, maka dapat diperoleh simpulan sebagai berikut

1. Modal sosial pada Subak Gede Bungan kapal berpengaruh positif sangat signifikan terhadap pengembangan usaha agribisnis pada Subak Gede Bungan kapal Kabupaten Tabanan Indikator modal sosial yang paling dominan adalah norma sosial.

2. Modal sosial berpengaruh positif sangat signifikan terhadap manajemen agribisnis di Subak Gede Bungan kapal. Dengan menerapkan modal sosial secara baik maka dapat mempermudah dalam penerapan kegiatan manajemen dengan baik sehingga tercipta pengembangan agribisnis yang baik serta berkelanjutan.

3. Manajemen agribisnis berpengaruh positif sangat signifikan terhadap pengembangan agribisnis di Subak Gede Bungan kapal Kabupaten Tabanan.. berhasil tidaknya kegiatan agribisnnis pada dasarnya tergantung pada efektif tidaknya menerapkan unsurunsur manajemen oleh subak pelaksana.

\section{Saran}

Berdasarkan hasil analisis dan pembahasan yang telah dilakukan dalam penelitian ini, maka dapat diberikan beberapa saran sebagai berikut :

1. Modal sosial yang dimiliki harus terus dijaga dan semakin ditumbuhkan atau dikuatkan di subak terutama dalam mengubah pola pikir mereka dengan lebih luwes bergaul.

2. Subak Gede Bungan Kapal harus memperluas jaringan sosial ke subak-subak sekitar seperti Subak Cepik, Subak, Tajen, dan Subak Keloda guna menunjang perluasan penjualan produk yang disediakan pada Koperasi subak.

3. Subak harus meningkatkan kelembagaaan agribisnis yang sudah dimiliki didalam subak sehingga dapat berinovasi dalam mengembangkan usaha agribisnisnya sehingga kegiatan agribisnis yang dilakukan lebih beragam.

4. Subak pelaksana kegiatan agribisnis harus diberikan pelatihan manajemen agribisnis mengenai pelaksanaan usaha agribisnis agar kegiatan-kegiatan agribisnis yang dilakukan dapat membantu peningkatan pendapatan subak.

5. Para pengurus subak harus diberikan pelatihan tentang, manajemen agribisnis dan pengembangan kegiatan agribisnis yang baik 
agar benar-benar menguasai materi tersebut sehingga mampu memberikan pembinaan maupun penyuluhan pada para anggota subak dalam menjalakan kegiatan agribisnis agar KUAT yang telah didirikan mampu berhasil dan sukses.

6. Penelitian ini masih memiliki berbagai kelemahan dan kekurangan, dinama penelitian ini tidak membahas secara mendalam analisis ekonomi pada pengembangan agribisnis di Subak Gede Bungan Kapal, oleh karenanya dipandang perlu dilakukan penelitian lebih lanjut dan lebih komprehensif mengenai analisis ekonomi pada pengembangan usaha agribisnis di Subak Gede Bungan Kapal.

\section{UCAPAN TERIMA KASIH}

Penulis mengucapkan terimakasih kepada Pengurus Subak Gede Bungan Kapal Dosen dan Staff Fakultas Pertanian Universitas Udayana, teman teman, dan keluarga yang turut serta membantu dalam penyelesaian penelitian.

\section{DAFTAR PUSTAKA}

Antara, 2005. Bahan Ajar Manajemen Agribisnis. Denpasar : Magister Agribisnis Program Pasca Sarjana Universitas Udayana.

Ghozali, I. 2008. Structural Equation Modeling Metode Alternatif dengan Partial Least Square. Edisi 2. Semarang : Universitas Diponegoro.

Ghozali, I. 2011. Structural Equation Modeling Metode Alternatif dengan Partial Least Square. Edisi 3. Semarang : Universitas Diponegoro.

Dananjaya, 2014." Pengaruh Jiwa Kewirausahaan dan Manajemen Agribisnis terhadap Keberhasilan Gapoktan Simantri di Kabupaten Tabanan (Tesis). Denpasar : Universitas Udayana, Program Pascasarjana.

Singarimbun, M. dan S.Effendi (Editor), 1989. Metode Penelitian Sosial. Jakarta : LP3ES.

Sedana,G. 2013." Modal Sosial Dalam Pengembangan Agribisnis Petani Pada Sistem Subak Di Bali'(Desertasi). Denpasar: Universitas Udayana,Program Pascasarjana.

Suyatna. 1982. Ciri - ciri Kedinamisan Kelompok Sosial Tradisional di Bali dan Peranannya dalam Pembangunan, Bogor: Fakultas Pasca Sarjana IPB. 


